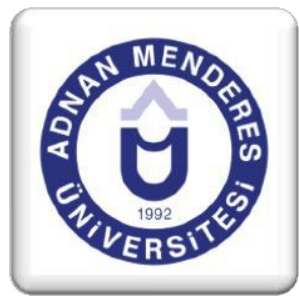

\title{
OECD Ülkelerinde Girişimcilik Faaliyetlerinin Ekonomik Büyüme Üzerine Etkisi: Panel Veri Analizi Dilek ŞAHİN $^{1}$
}

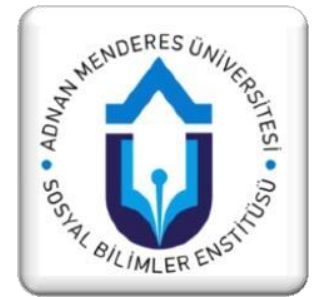

ÖZET

$\mathrm{Bu}$ çalışmanın temel amacı, OECD ülkelerinde girişimcilik faaliyetleri, finansal gelişme ve sermaye birikiminin ekonomik büyüme üzerindeki etkisini analiz etmektir. Çalışmada 2002-2015 dönemi esas alınarak panel veri yöntemi kullanılmıştır. Analiz bulgularında, girişimcilik faaliyeti, finansal gelişme ve sermaye birikiminin ekonomik büyüme üzerinde pozitif ve istatistiksel olarak anlamlı etkiye sahip olduğu görülmüștür. Ayrıca girişimcilik faaliyetlerindeki \%1 birimlik artış ekonomik büyümede $\% 0.044$ oranında artışa neden olmaktadır. Sermaye birikiminde \%1 birimlik artış ise ekonomik büyümeyi \% 0.192 oranında artırmaktadır. Finansal gelişmede $\% 1$ birimlik artış ekonomik büyümeyi \% 0.020 oranında artırmaktadır.

Anahtar Kelimeler: Girişimcilik, Finansal Gelişme, OECD Ülkeleri, Panel Veri Analizi.

Jel Kodu: FOO, M2, O1.

\section{Entrepreneurship Activities Effect on Economic Growth in OECD Countries: Panel Data Analysis}

\begin{abstract}
Abtsract
The main objective of this study is to analyze the effects of entrepreneurial activities, financial development and capital accumulation on economic growth in OECD countries. In this study it was used panel data method based on 2002-2015 period. In the analysis findings, entrepreneurial activity, financial development and capital accumulation have a positive and statistically significant effect on economic growth. In addition $1 \%$ increase in entrepreneurial activity causing an increase of $0.044 \%$ in economic growth. $1 \%$ increase in capital accumulation increases economic growth by $0.192 \% 1 \%$ increase in financial growth increases economic growth by $0.020 \%$.
\end{abstract}

Keywords: Entrepreneurship, Financial Development, OECD Countries, Panel Data Analysis.

JEL Classification: FOO, M2, O1.

\footnotetext{
${ }^{1}$ Dr.Öğr.Üyesi., Sivas Cumhuriyet Üniversitesi Turizm Fakültesi, Turizm İşletmeciliği Bölümü. E-mail: dilek58sahin@hotmail.com.
} 


\section{Giriş}

Girişimcilik uzun zamandan beri ekonomik büyümenin önemli bir mekanizması olarak görülmektedir. Girişimci, iktisat teorisinde temel üretim faktörleri olan emek, sermaye ve doğal kaynakları bir araya getirerek üretim yapan faktördür. Girişimcinin riski alabilmesi ve piyasadaki belirsizlik durumunda işletmeyi en iyi şekilde yönetmesi sayesinde işletme faaliyetlerinde başarıya ulaşarak devamlılı̆̆ını sağlamaktadır (Karagöz, 2016:267). Girişimcilik, bir bireyin veya bireylerin oluşturdukları ortaklıkların mal ve hizmetlerin üretilmesi veya dağıtılmasını kapsayan, kâr amaçlı bir iş ünitesinin kurulması, sürdürülmesi ve büyütülmesi sorumluluğunu almalarına yönelik faaliyetler bütünüdür. En genel haliyle girişimcilik bazı imkânlardan faydalanmak için bazı kaynakların irdelendiği, değerlendirildiği ve mevcut kaynaklardan en iyi şekilde fayda elde etme süreci olarak ifade edilebilir. Wennekers ve Thurik (1999) göre, girişimci bireysel olarak veya ekip halinde mevcut organizasyonların içinde veya dışında yeni ekonomik firsatları algılayan, yeni firsatlar çıkaran, belirsizliği ve engelleri göze alarak kaynakların ve işletmelerin yer seçimi hakkında karar veren kişidir. Hebert ve Link (1989)'a göre ise, girişimci kuruluş yeri seçimini, iş formunu ve malların, kaynakların veya kurumların kullanımını etkileyen kararlar alan ve sorumluluk taşıyan iktisadi aktörlerdir.

Girişimcilik faaliyetinin ekonomik ve sosyal fonksiyonu bulunmaktadır. Girişimciliğin ekonomik alandaki fonksiyonları arasında; istihdamı artırma, ekonomik büyümeyi hızlandırma, yeni endüstrilerin ortaya çıkması, refah düzeyinin yükseltilmesi ve tabana yayılarak orta sınıfın güçlendirilmesi, bölgesel gelişmişlik farklarının azaltılması yer almaktadır. Girişimciliğin sosyal alandaki fonksiyonları arasında; teknolojik buluşların toplum yararına yenilikçi ürün ve hizmetlere dönüştürülmesinde, değer yaratmada, toplumsal yapıda değişimci/yenilikçi bir sürecin başlatılmasında, risk üstlenme, yenilikçi ve öncü olma niteliğinden ötürü toplumların değişim ve gelişimini sağlayarak işlevini gerçekleştirmektedir (Ball1, 2017:150). Tablo 1'de görüldüğü üzere girişimciliğin; "Schumpeteryan Girişimciler, İç Girişimciler ve Yönetici İşletme Sahipleri” olmak üzere üç çeşidi bulunmaktadır. Kendi hesabına çalışan ve ücretli çalışanlardan girişimci niteliğe sahip olanlar Schumpeter tipi girişimciler ve iç girişimciler iken; kendi hesabına çalışan yönetici işletme sahipleri de Schumepeter'e göre girişimci olarak kabul edilmektedirler. Yönetici işletme sahipleri, girişimci-yönetici ayrımında girişimci niteliklerini taşımasalar da girişimci olarak değerlendirilmektedirler. Buna karşın, ücretli çalışan icra kurulu yöneticileri hem kendi hesabına çalışanlar, hem de girişimci olarak kabul edilmemektedirler (Wennekers ve Thurik ,1999: 47).

Tablo 1. Girişimcilik Türleri

\begin{tabular}{|l|l|l|}
\hline & Kendi Hesabına Çalışanlar & Ücretli Çalışanlar \\
\hline Girişimci & Schumputer Tipi Girişimler & İç Girişimler \\
\hline Yönetici & Yönetici İşletme Sahipleri & İcra Kurulu Yöneticileri \\
\hline
\end{tabular}

Kaynak: Wennekers ve Thurik ,1999: 47.

Audretsch ve Thurik (2004) girişimcilik faaliyetinin ekonomik büyüme üzerindeki etkisini üçe ayırarak incelenmiştir. İlki girişimciliğin bilgi yayılımını sağlamasıdır. Bu bağlamda, Romer (1986), Lucas (1978, 1993), Grossman ve Helpman (1991) bilgi yayılımının ekonomik büyümenin sağlanmasında önemli bir mekanizma olduğunu ileri sürmektedir. Ayrıca girişimcilik faaliyetleri önemli geçiş mekanizması olarak nitelendirilmektedir. İkinci olarak, girişimcilik faaliyetleri artan rekabet ve girişimci sayısındaki artış ile birlikte ekonomik büyüme için gerekli olan sermaye birikiminin artmasına yardımc1 olur. $\mathrm{Bu}$ 
bağlamda Jacobs (1969) ve Porter (1990) rekabetin yerel tekellere nazaran bilgi dışsallıkları için daha uygun olduğunu ifade etmektedir. Üçüncüsü girişimcilik faaliyetlerinin firmalar arasında çeşitlilik sağlayarak ekonomideki çıktı düzeyi için sermaye yaratmasıdır. Girişimcilik faaliyetleri sadece belirli bir bölgede girişimci sayısını artırmakla kalmaz aynı zamanda girişimcilik faaliyetlerinin çeşitlenmesine yardımcı olur. Ortaya çıkan farklılık ekonomik büyüme potansiyelini artıracaktır (Carree ve Thurik, 2005b:5-6).

Şekil 1'de girişimcilik ve ekonomik büyüme ilişkisine yer verilmiştir. Şekilden de anlaşılacağı üzere, girişimciliğin bireysel faaliyetlerle, ekonomik büyümenin ise firmalar, endüstriler, bölgeler ve ülkelerle ilgili bir kavram olduğu görülmektedir. Esasında girişimcilikle ekonomik büyüme arasındaki bağlantı, bireysel seviye ile toplam seviye arasındaki ilişkiden ibarettir. Bu kapsamda girişimcilikle ekonomik büyüme arasındaki ilişki, bireysel, firma ve makro düzeyde dikkate alınmaktadır. Girişimcilik faaliyeti firma düzeyinde olup, girişimciler kişisel özelliklerini ve isteklerini eyleme dönüştürebilmek isterler. Firma düzeyindeki girişimcilik faaliyetleri yenilikler sonucu ortaya çıkmaktadır. Bu yenilikler, yeni piyasalara girme, yenilikçi firma kuruluşları sayesinde, üretim, süreç ve organizasyonel yenilikler şeklinde gerçekleşmektedir. Bu tür girişimci eylemler ve yeni düşünceler arasındaki bir rekabet süreci sürekli olarak piyasalar için en uygun endüstrilerin ve firmaların seçimine yol açmaktadır. Çeşitlilik, rekabet, seçim ve taklit genişlemekte, ulusal ve bölgesel ekonomilerin verimlilik potansiyeli, eski firmaların değiştirilmesi ya da yerinden edilmesi yoluyla olumlu şekilde dönüşmektedir. Ancak bu dinamik süreçlerin sonucu birtakım koşulların varlığına bağlı görülmektedir. Bu koşullardan ilki ulusal (ya da bölgesel) kültürel çevreye ve kurumsal kültüre atıfta bulunmaktadır. Kültür ve girişimcilik arasındaki ilişkinin anlaşılmasında basit ve açık bir süreç söz konusu değildir. Bu süreç hala tam anlamıyla bilinmemektedir. İkincisi ise kurumsal çevredir ki, kurumsal çevre hem ulusal seviyede hem de firma içerisinde, bireylerin çabalarının eyleme dönüşümünün teşvik edicisi ve onları engelleyen gereksiz unsurların belirleyicileri olarak tanımlanabilmektedir (Carree ve Thurik, 2005a: 586-587).

Şekil 1.Girişimcilik ve Ekonomik Büyüme İlişkisi

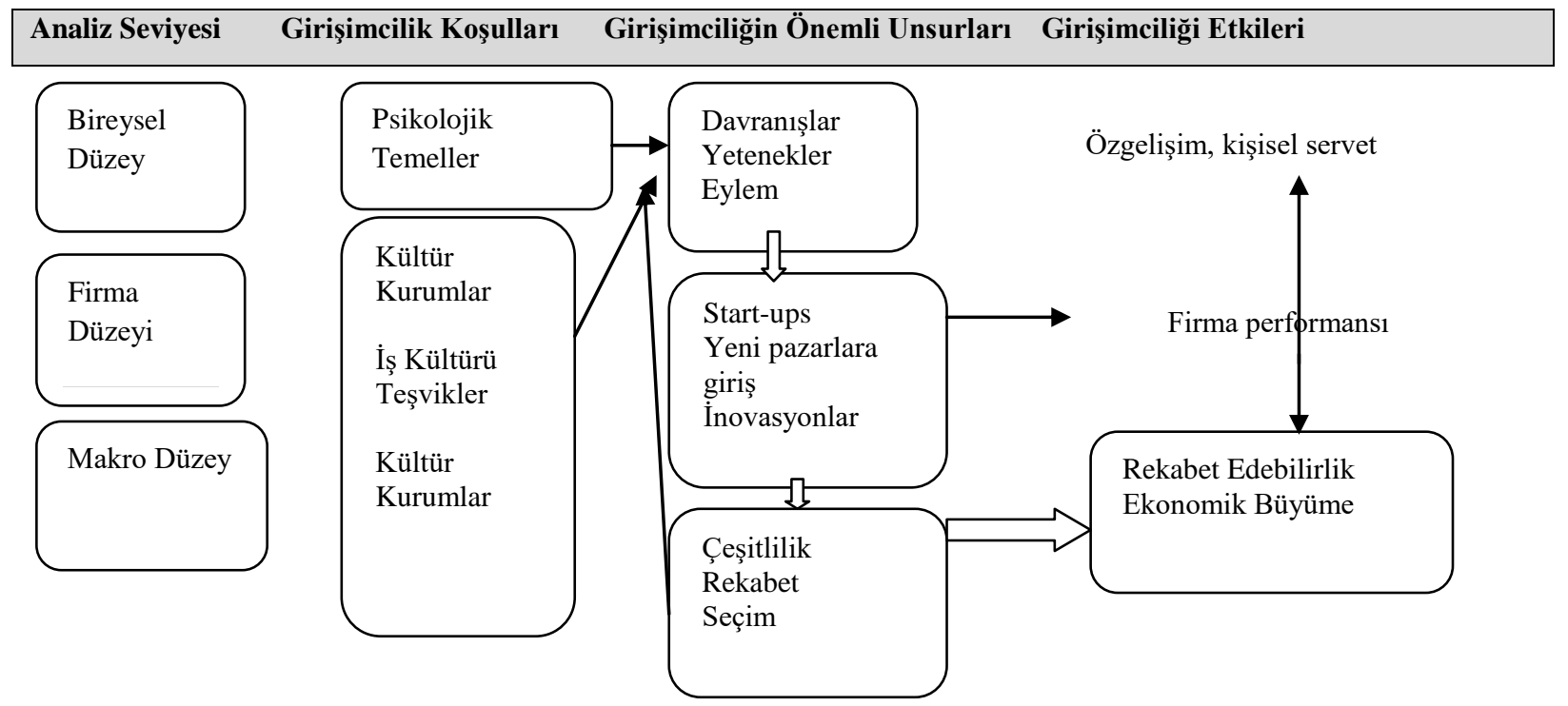

Kaynak: Wennekers ve Thurik, 1999: 51. 
$\mathrm{Bu}$ çalışmanın esas amacı, ele alınan OECD ülkelerinde girişimcilik faaliyeti, finansal gelişme ve sermaye birikiminin ekonomik büyüme ile olan ilişkisini analiz etmektir. $\mathrm{Bu}$ kapsamda çalışmada, 2002-2015 dönemleri arası değerlendirmeye alınarak panel veri yöntemi kullanılmıştır. Çalışmada bağımlı değişken olarak ekonomik büyümeyi temsilen reel kişi başına düşen milli gelir (2010 sabit fiyatlarıyla), bağımsız değişken olarak finansal gelişmeyi temsilen özel sektöre kullandırılan kredilen GSYH \% payı, sermaye oluşumu (2010 sabit fiyatlarıyla) ve toplam girişimcilik faaliyeti değişkeni kullanılmıştır. Çalışmanın devam eden bölümleri şu şekilde organize edilmiştir. Giriş kısmını takip eden ikinci bölümde konu ile ilgili literatür taramasına yer verilmiştir. Veri setinin yer aldığı üçüncü bölümün ardından yöntem ve ampirik bulguların yer aldığı dördüncü bölüme yer verilmiştir. Çalışma beşinci bölüm olan sonuç bölümü ile sonlandırılmıştır.

\section{Literatür Taraması}

Girişimciliğin ekonomik açıdan öneminin anlaşılmaya başlamasıyla birlikte, girişimciliğin ekonomik büyüme üzerindeki etkisi giderek artmaya başlamıştır. Son dönemlerde, özellikle GEM veritabanının gelişmesiyle birlikte yapılan ampirik çalışmalarının sayısının arttığ görülmektedir. Tek ülke örneklerinde yürütülen zaman serileri analizlerinde girişimcilik düzeyini temsilen patent ve yeni kurulan şirket sayısı göstergelerinin, çok ülkeli panel veri analizlerinde ise elverişli olması nedeniyle GEM verilerinin kullanıldığı görülmektedir. Literatürde yapılan çalışmalardan elde edilen bulgular genel olarak girişimciliğin ekonomik büyümeyi olumlu yönde etkilediği şeklindedir.

Bu kapsamda Literatürde yapılan çalışmalardan bazılarını şu şekilde özetlemek mümkündür: Stam ve Stel (2009), farklı gelişme düzeylerine sahip 36 ülkede 2002-2005 dönemleri arasında girişimciliğin ekonomik büyüme üzerindeki etkisini analiz etmiştir. Analiz bulguları girişimciliğin düşük gelirli ülkelerde ekonomik büyüme üzerinde etkisinin olmadığını göstermiştir. Geçiş ekonomilerinde ve yüksek gelirli ülkelerde girişimciliğin ekonomik büyüme üzerinde etkisinin daha fazla etkiye sahip olduğu görülmüştür. Amaghauss ve Ibourk (2013), 19 OECD ülkesinde 2001-2009 dönemleri arasında girişimcilik ve ekonomik büyüme arasındaki ilişkiyi analiz etmiş̧ir. Girişimcilik için; girişimcilik faaliyetleri ve potansiyel inovasyon değişkenleri kullanılmıştır. Panel veri analizinin uygulandığı çalışmada, girişimcilik faaliyetlerinin ekonomik büyüme üzerinde pozitif ve istatistiksel olarak anlamlı etkisinin olduğu görülmüştür. Konuyla ilgili yapılan başka bir çalışmada Chen (2014), 1987-2012 dönemleri arasında Tayvan'da ekonomik büyüme, girişimcilik ve istihdam arasındaki ilişkiyi analiz etmiştir. Çalışmada VAR modeli uygulanmıştır. Analiz bulguları, girişimciliğin ekonomik büyüme ve istihdama katkıda bulunduğunu göstermiştir. Galindo ve Mendez (2014),2002-2013 dönemleri arasında 13 gelişmiş ülkede ekonomik büyüme, girişimcilik ve inovasyon arasındaki ilişkiyi panel veri yöntemi ile analiz etmiştir. Analiz bulgularında inovasyon ve girişimcilik üzerinde çok sayıda faktörün etkili olduğu görülmüştür. Ayrıca ekonomik faaliyetlerin inovasyon ve girişimcilik faaliyetlerini artırdığ 1 görülmüştür. Karagöz (2016), 1968-2012 dönemleri arasında Türkiye'de girişimcilik ve ekonomik büyüme arasındaki ilişkiyi vektör otoregresyon modeli kullanarak analiz etmiştir. Analiz sonucunda, Türkiye'de girişimcilik ve ekonomik büyüme arasında kısa dönemde pozitif bir ilişki olduğu görülmüştür. Granger nedensellik analizinde ise iki değişken arasında nedensellik ilişkisinin olmadığı görülmüştür. Başka bir çalışmada Urbano ve Aparicio (2016), 2002-2012 dönemleri arasında 43 ülkede girişimcilik türlerinin ekonomik büyüme üzerindeki etkisini analiz etmiştir. Analiz bulguları, girişimcilik faaliyetlerinin ekonomik büyüme üzerinde pozitif etkiye sahip olduğunu göstermiştir. Özkul ve Örün (2017), 9 OECD ülkesinde 2002-2013 dönemleri arasında girişimcilik ve inovasyonun 
ekonomik büyüme üzerindeki etkisini panel veri analizi ile incelemiştir. Bu kapsamda oluşturulan beş model içinde teknolojik inovasyon yoğunluğunun pozitif ve anlamlı bir etkiye sahip olduğu, yeni firma yaratma olarak değerlendirilen girişimciliğin ise sadece olgunlaşmamış girişimcilik oranı ve zorunluluğa dayalı girişimcilik faaliyeti olarak girişimciliğin kurgulandığı modellerde ekonomik büyüme üzerinde pozitif ve anlamlı bir etkiye sahip olduğu bulunmuştur. Rusu ve Roman (2017), 2002-2015 dönemleri arasında 18 $\mathrm{AB}$ ülkesinde girişimcilik faaliyetinin dinamiklerini panel veri yöntemi ile analiz etmiştir. Analiz bulgularında, enflasyon oranı, doğrudan yabancı sermaye yatırımları, finansmana erişim, toplam vergi oranının girişimcilik faaliyetini belirleyen başlıca makroekonomik unsurlar olduğu görülmüştür. Ayrıca bu faktörlerin toplam girişimcilik faaliyeti üzerinde önemli etkisinin olduğu sonucuna ulaşılmıştır. Doran vd., (2018), 2004-2011 dönemleri arasında ele alınan 55 ülkede 14 farklı girişimcilik göstergeleri ile ekonomik büyüme arasındaki ilişkiyi analiz etmiştir. Analiz bulgularında yüksek gelir grubundaki ülkelerde girişimcilik faaliyetlerindeki artışın ekonomik büyümeyi hızlandırdığı görülmüştür. Ortadüşük gelirli ülkelerde ise girişimcilik faaliyetlerinin ekonomik büyümeyi negatif yönde etkilediği görülmüştür.

\section{Veri Seti}

Bu çalışma 8 OECD ülkesinde (Belçika, Finlandiya, Hollanda, Norveç, Slovenya, İspanya, İngiltere, ABD) 2002-2015 dönemleri arasında ekonomik büyüme, girişimcilik faaliyetleri, finansal gelişme ve sermaye birikimi arasındaki ilişki analiz edilmiştir. Çalışmada panel veri analizi kullanılmıştır. Dönem aralığı ve ülke sayısı toplam girişimcilik faaliyetine ilişkin veri kısıtı dikkate alınarak belirlenmiştir. Geriye kalan OECD ülkelerinin girişimcilik verileri yeterli uzunlukta ve kesintisiz olarak temin edilemediğinden ötürü analiz dışı bırakılmıştır. Çalışmada kullanılan model literatürden yola çıkılarak oluşturulmuştur. Amprik model (1) nolu Eşitlikte gösterilmiştir. Model oluşturulurken değişkenlerin logaritmik formları esas alınmıştır. Çalışmada kullanılan verilere ve verilerin alındığı kaynaklara Tablo 2'de yer verilmiştir.

$\ln P G D P i t=\alpha i t+\beta 1 \ln G R i t+\beta 2 \ln F G i t+\beta 3 \ln S E R i t+\varepsilon i t$

(1) nolu Eşitlikte PGDP, reel kişi başına düşen geliri, GR toplam girişimcilik faaliyetini, FG özel sektöre kullandırılan kredilerin GSYH \% payını, SER sermaye oluşumunu göstermektedir. Girişimciliğe ilişkin verilere GEM'in internet sitesinden ulaşılmıştır. Girişimcilik verisinin elde edildiği GEM'in yapmış olduğu çalışmalarda dünya genelinde girişimsel tutum, faaliyet ve isteklerdeki farkl1lıkları ölçmekte, girişimcilik düzeylerini belirleyen faktörleri ortaya çıkararak politika uygulamalarını tanımlamaktadır. GEM tarafindan sağlanan girişimcilik göstergelerini şu şekilde açıklamak mümkündür: Toplam Girişimcilik Faaliyeti (TGF): 18-64 yaş arası nüfus içinde iş kuran veya en fazla 3,5 yıldır faaliyet gösteren bir işletmeye sahip olanların oranıdır; Yeni Oluşan Girişimcilik Faaliyeti $(Y G F)$ : Henüz iş kurmuş olanların sayısının 18-64 yaş arası nüfusa oranı; Genç İşletme Girişimcilik Faaliyeti $(G G F)$ : 3,5 yıldan az faaliyette olan işletmelerin sahiplerinin sayısının 18-64 yaş arası nüfusa oranı; Kurulu İşletme Sahipleri (KiS): 3,5 yıldan daha uzun süredir faaliyet göstermekte olan işletmelerin sahiplerinin 18-64 yaş arası nüfusa oranı; Fırsatçı Girişimcilik Faaliyeti $(F G F)$ : TGF içinde olan ve bir fursatı değerlendirerek girişimcilik faaliyetinde bulunan bireylerin 18-64 yaş arası nüfusa oran1; Zorunlu Girişimcilik Faaliyeti $(Z G F)$ : TGF içinde olan ve zorunluluktan dolayı girişimcilik faaliyeti gösteren bireylerin 1864 yaş arası nüfusa oranıdır. Yeni kurulmuş işletmeler endeksinin kurulu işletmeler endeksine oranı bir ekonomide girişimcilik faaliyetinin canlılığını gösterir. Bu çalışma kapsamında GEM sitesinden girişimcilik göstergesi olarak toplam girişimcilik faaliyeti değişkeni dikkate alınmıştır. Çalışmadaki diğer verilere ise Dünya Bankasından ulaşılmıştır. 
Tablo 2.Çalışmada Kullanılan Değişkenler ve Açıklamalar

\begin{tabular}{|c|l|l|}
\hline Değişken & Açıklama & Kaynak \\
\hline PGDP & $\begin{array}{l}\text { Kişi başına gelir (2010 sabit } \\
\text { fiyatlarıyla) }\end{array}$ & \\
\hline SER & $\begin{array}{l}\text { Sermaye oluşumu (2010 sabit } \\
\text { fiyatlarıyla) }\end{array}$ & Dünya Bankası \\
\hline FG & $\begin{array}{l}\text { Özel Sektöre Kullandıran } \\
\text { Kredilerin GSYH \% Payı }\end{array}$ & \\
\hline GR & Toplam Girişimcilik Faaliyeti & \multirow{2}{*}{ GEM } \\
\hline
\end{tabular}

\section{Yöntem ve Analiz Sonuçları}

Panel veri analizini yapmadan önce verilerin durağan olup olmadığına da bakılmaktadır. Panel veri analizinde verilerin durağan olup olmadığını belirlemek için çoğunlukla birim kök testi uygulanmaktadır. Ancak birim kök testi zaman aralığı kısa olan çalışmalarda risk teşkil etmektedir. Yani normalde durağan olmasına rağmen yapılan birim kök testi sonucunda durağan olmama problemi ortaya çıkmaktadır. Bu çalışmada da zaman aralığının kısa olmasından dolayı aynı problemle karşılaşıldığı için birim kök testi yapılmamıştır.

Panel veri modellerinde, klasik modelin geçerliliği diğer bir ifadeyle birim ve/veya zaman etkilerinin olup olmadığının tespitinde kullanılan testlerden biri "Olabilirlik Oranı Testi" (LR)'dir. $\mathrm{Bu}$ teste $\mathrm{H}_{0}$ hipotezi "klasik model doğrudur" şeklinde kurulmaktadır. $\mathrm{H}_{0}$ hipotezi reddedilirse, birim, zaman veya hem birim hem de zaman etkilerinin olduğuna diğer bir ifadeyle klasik modelin uygun olmadığına karar verilmektedir. Tablo 3'de görüldügüü üzere, LR testi sonucunda sadece birim etkinin olduğu görülmektedir. $\mathrm{Bu}$ nedenle model tek yönlüdür.

Tablo 3. LR Testi

\begin{tabular}{|c|c|c|}
\hline \multicolumn{3}{|c|}{ LR Testi } \\
\hline & Birim Etki & Zaman Etki \\
\hline $\mathbf{X}^{\mathbf{2}}$ & 505.97 & 0.00 \\
\hline Prob & 0.000 & 1.000 \\
\hline
\end{tabular}

Yapılan LR testi sonucunda birim ve/veya zaman etkilerinin olduğu anlaşıldıktan sonra, bu etkilerin sabit mi yoksa tesadüfi mi olduğuna karar verilmesi gerekir. Bu bağlamda karar aşamasında Hausman testi tahminciler arasında seçim yapmak amacıyla kullanılmaktadır. Sabit ve tesadüfi etkiler modelleri arasındaki en önemli farklardan biri, birim etkilerin bağımsız değişkenlerle korelasyonlu olup olmadığı hususudur. Eğer aralarında korelasyon söz konusu değilse, tesadüfi etkiler modeli daha etkin ve geçerlidir. Hausman testinde; $\mathrm{H}_{0}=$ Açıklayıcı değişkenler ve birim etki arasında korelasyon yoktur şeklindedir. Bu nedenle tesadüfi etkiler tahmincisi daha etkin olduğundan kullanımı uygun olacaktır. $\mathrm{H}_{\mathrm{A}}=$ Açıklayıcı değişkenler ile birim etki arasında korelasyon vardır şeklindedir. Bu nedenle sabit etkiler modeli tutarlı olduğundan tercih edilmelidir. Tablo 4'de görüldüğü üzere, tesadüfi etkiler tahmincisinin tutarlı ve etkin olduğu, ancak sabit etkiler tahmincisinin tutarsız olduğu sonucuna ulaşılmıştır. Diğer bir anlatımla, Hausman testi birim etkinin tesadüfi olduğunu göstermektedir. Yapılan bu analiz tek yönlü tesadüfi etki modelidir. 
Tablo 4. Hausman Testi

\begin{tabular}{|c|c|}
\hline \multicolumn{2}{|c|}{ Hausman Testi } \\
\hline $\mathbf{X}^{\mathbf{2}}$ & 1.17 \\
\hline Prob & 0.7603 \\
\hline
\end{tabular}

Levene (1960), normal dağılım varsayımının gerçekleşmediği durumda dirençli bir heteroskedasite testi önermiştir. Brown ve Forsythe (1974) Levene'nin test istatistiğindeki ortalama yerine aykırı gözlemlere karşı dirençli bir yapı sağlayan kırpılmış ortalamaya dayalı alternatif yerel tahminciler önermişlerdir. Tablo 5 'de görüldüğü üzere tesadüfi etkiler modelinde heteroskedasitenin varlığını test etmek için Levene, Brown ve Forsythe'nin testleri kullanılmıştır. 8 birim için kalıntıların ortalaması ve standart sapmalarına da yer verilen bu teste Levene, Brown ve Forsythe'nin test istatistikleri (W0, W50, W10) $(7,104)$ serbest dereceli Snedecor F tablosu ile karşılaştırılarak "birimlerin varyansları eşittir" şeklinde kurulan $\mathrm{H}_{0}$ hipotezi reddedilmektedir. Başka bir ifadeyle modelde heteroskedasite bulunmaktadir.

Tablo 5. Levene, Brown and Forsythe Testi

\begin{tabular}{|c|c|}
\hline \multicolumn{2}{|c|}{ Levene, Brown and Forsythe Test } \\
\hline W0 & $\operatorname{df}(7,104) \operatorname{Prob}(0.0000)$ \\
\hline W50 & $\operatorname{df}(7,104) \operatorname{Prob}(0.0038)$ \\
\hline W10 & $\mathrm{df}(7,104) \operatorname{Prob}(0.00019$ \\
\hline
\end{tabular}

Tablo 6'da modelde otokorelasyonun olup olmadığı sınanmıştır. Otokorelasyonun olup olmadığının tespitinde Bhargava, Franzini ve Narendranathan tarafından önerilen Durbin Watson testi ve Baltagi-Wu tarafından önerilen yerel en iyi değişmez testi kullanılmıştır. Testlerin her ikisinde de otokorelasyon katsayısının sıfıra eşit olduğu $(\mathrm{p}=0) \mathrm{H}_{0}$ hipotezi test edilmektedir. Literatürde test istatistiklerinin 2'den küçükse otokorelasyonun önemli olduğu yorumu yapılmaktadır. Tabloda görüldüğü üzere, her iki test içinde değerler 2'den küçüktür dolayısıyla tesadüfi etkiler modeli için otokorelasyon sorunun önemli olduğu şeklinde yorum yapılmaktadır. Ayrıca otokorelasyonun olup olmadığı Lagrance Çarpanı (LM) testi ile de kontrol edilmiştir. LM testinde otokorelasyon için sonuçlara bakıldığında, "otokorelasyon yoktur" şeklindeki temel hipotezin reddedildiği görülmektedir. Bu bağlamda tesadüfi etkiler modelinde otokorelasyonun mevcut olduğu söylenebilir.

Tablo 6. Otokorelasyon Testi

\begin{tabular}{|c|c|c|}
\hline $\begin{array}{c}\text { Modified Bhargava } \\
\text { et al. Durbin- } \\
\text { Watson Test }\end{array}$ & $\begin{array}{c}\text { Baltagi-Wu LBI } \\
\text { Testi }\end{array}$ & LM Testi \\
\hline 0.66619 & 1.05604 & $116.49(0.000)^{*}$ \\
\hline *Olas1l1k değeri
\end{tabular}


Tesadüfi etkiler modelinde birimler arası korelasyonun varlığını sınamak için Pesaran, Friedman ve Frees testleri kullanılmıştır. Tablo 7'de görüldüğü üzere, her üç testte de $\mathrm{H}_{0}$ hipotezi kabul edilmekte ve dolayısıyla birimler arası korelasyonun olduğu anlaşılmaktadır.

Tablo 7. Birimler Arası Korelasyon

\begin{tabular}{|c|c|c|}
\hline Pesaran Testi & Friedman Testi & Frees Testi \\
\hline 7.255 & 40.400 & 1.275 \\
$\operatorname{Prob}(0.000)$ & Prob $(0.000)$ & Alpha $=0.10: 0.1841$ \\
& & Alpha $=0.05: 0.2431$ \\
& & Alpha $=0.01: 0.3603$ \\
\hline
\end{tabular}

Modelde tek yönlü birim etkinin olduğu, birim etkinin de tesadüfi olduğu anlaşıldıktan sonra modelde heterosdekastiki, otokorelasyon ve birimler arası korelasyon probleminin olup olmadığına bakılmıştır. Heteroskedasite problemin olup olmadığı tespit etmek için Levene, Brown ve Forsythe testi yapılmış ve modelde heteroskedasite probleminin olduğu tespit edilmiştir. Otokorelasyon probleminin olup olmadığını tespit etmek için Bhargava, Franzini ve Narendranathan tarafindan önerilen Durbin Watson testi ve Baltagi-Wu tarafindan önerilen yerel en iyi değişmez testi ve LM testi yapılmış ve modelde otokorelasyonun olduğu görülmüştür. Ayrica Pesaran, Friedman ve Frees testleri ile birimler arası korelasyonun olup olmadığı tespit edilmiş ve modelde birimler arası korelasyonun olduğu görülmüştür.

Yapılan varsayımların testleri neticesinde heterosdekastiki, otokorelasyon ve birimler arası korelasyon sorunu içeren bir modelin, heterosdekastiki, otokorelasyon ve birimler arası korelasyona dirençli tahminciler ve yöntemlerle yeniden tahmin edilmesi gerektiği anlaşılmıştır. $\mathrm{Bu}$ bağlamda, çalışmada modeldeki mevcut sorunların giderilmesinde "Driscoll ve Kraay Tahmincisi" kullanılmıştır. Bu doğrultuda elde edilen sonuçlar Tablo 8 'de gösterilmiştir. Bulguların yer aldığı Tablo 8 incelendiğinde, bağımlı değişken ekonomik büyüme üzerinde girişimcilik faaliyetleri, finansal gelişme ve sermaye birikiminin pozitif ve istatistiksel olarak anlamlı etkilerinin olduğu görülmektedir. Bu bağlamda girişimcilik faaliyetlerindeki \%1 birimlik artış ekonomik büyümede \%0.044 oranında artışa neden olmaktadır. Sermaye birikiminde \%1 birimlik artış ise ekonomik büyümeyi \% 0.192 oranında artırmaktadır. Son olarak finansal gelişmede (özel sektöre kullandırılan kredilerde) $\% 1$ birimlik artışın ekonomik büyümeyi \% 0.020 oranında artırdığı görülmektedir. Analiz sonuçlarından da anlaşılacağı üzere girişimcilik faaliyetleri, finansal gelişme ve sermaye birikimin ele alınan OECD ülkelerinde ekonomik büyümeyi artırdığı görülmektedir.

Tablo 8.Analiz Sonuçları

\begin{tabular}{|c|c|c|c|}
\hline Değişken & Katsayı & $\begin{array}{c}\text { Drisc/Kraay } \\
\text { Standart Hata }\end{array}$ & Olasılık Değeri \\
\hline GR & 0.0440 & 0.0143 & $0.018^{* *}$ \\
\hline SER & 0.1925 & 0.0302 & $0.000^{*}$ \\
\hline FG & 0.0207 & 0.0055 & $0.007^{*}$ \\
\hline Sabit & 5.5168 & 0.7840 & $0.000^{*}$ \\
\hline
\end{tabular}

Not: *\%1** \%5, seviyesinde anlamlılık düzeyini göstermektedir. GR, toplam girişimcilik faaliyetlerini, SER sermaye birikimini, FG finansal gelişmeyi temsil etmektedir. 


\section{Sonuç}

Günümüzde ekonomik büyümenin en temel yapı taşlarından biri olan girişimcilik faaliyetinin her geçen gün daha fazla önemli hale geldiği görülmektedir. Ekonomik kaynakların üretkenliğin düşük olduğu alanlardan üretkenliği yüksek olan alanlara aktarılmasını sağlaması, yenilik ve yaratıcılığa olanak tanıması, ortaya çıkardığı istihdam firsatlarıyla işsizlik sorununa önemli bir çözüm sunması girişimciliği günümüzün yoğun rekabet ortamında önemli bir konuma yerleşmesine olanak tanımıştır. Ekonomik büyüme literatüründe, girişimcilik ekonomik büyümeyi etkileyen önemli faktörler arasında saymakla birlikte, ekonomik büyümeyi açıklayan çoğu ampirik modelde girişimcilik faktörünün ihmal edildiği görülmektedir. Bunun esas nedeni; girişimcilik faaliyetlerinin işlevleştirilmesinin ve ölçülmesinin zorluğundan kaynaklanmaktadır. Bununla birlikte son yıllarda dünyada girişimciliğin geliştirilmesi ve mevcut durumun ortaya konulması için kurulan GEM, girişimcilik faaliyetlerinin ekonomik büyüme üzerindeki etkisinin incelenmesine katkıda bulunmaktadir.

Bu kapsamda yapılan bu çalışmada, 8 OECD ülkesinde 2002-2015 dönemleri arasında girişimcilik faaliyetleri, ekonomik büyüme, finansal gelişme ve sermaye birikimi arasındaki ilişki panel veri yöntemi ile analiz edilmiştir. Girişimcilik faaliyetini temsilen GEM sitesinden elde edilen Toplam Girişimcilik Faaliyeti (18-64 yaş arası nüfus içinde iş kuran veya en fazla 3.5 yıldır faaliyet gösteren bir işletmeye sahip olanların oranıdır), ekonomik büyümeyi temsilen reel kişi başına gelir, finansal gelişmeyi temsilen özel sektöre kullandırılan kredilerin GSYH \% payı değişkeni ve sermaye birikimi değişkeni kullanılmıştır. Analiz bulgularında; girişimcilik faaliyetlerindeki \%1 birimlik artış ekonomik büyümede $\% 0.044$ oranında artırdığg görülmüştür. Sermaye birikiminde $\% 1$ birimlik artış ise ekonomik büyümeyi \% 0.192 oranında artırmaktadır. Son olarak finansal gelişmede $\% 1$ birimlik artışın ekonomik büyümeyi \% 0.020 oranında artırdığı görülmektedir.

Analiz sonuçlarından da anlaşılacağı üzere; girişimcilik faaliyetleri, finansal gelişme ve sermaye birikiminin ele alınan OECD ülkelerinde ekonomik büyümeyi artırdığı görülmektedir. Bu bilgiler 1şığında, girişimcilik eğitimlerinin artırılarak, girişimcilik kültürünün oluşturulması için gerekli desteklerin sağlanması son derecede önemlidir. $\mathrm{Bu}$ nedenle, ekonomik büyümeyi hızlandırmaya yönelik politika tasarımları içerisinde girişimcilik temelli politikalara ağırlık verilmelidir. 


\section{KAYNAKÇA}

AMAGHAUSS, J., IBOURK, A.(2013). Entrepreneurial Activities, Innovation and Economic Growth: The Role of Cyclical Factors Evidence from OECD Countries for the Period 2001-2009. International Business Research, 6(1), 153-162.

BALLI, A. (2017). Girişimcilik ve Girişimci Tipolojileri. Süleyman Demirel Üniversitesi Sosyal Bilimler Enstitüsü Dergisi, 4(29), 143-166.

CARREE, M., THURIK, R.(2005a).The Impact of Entrepreneurship on Economic Growth. 557-594.

https://personal.eur.nl/thurik/Research/Articles/The\%20impact\%20of\%20ntreprene urship\%20on\%20economic\%20growth\%20-\%20thurik\%20chapter.pdf.

CARREE, M., THURIK, R. (2005b). Understanding the Role of Entrepreneurship for Economic Growth. Discussions Papers on Entrepreneurship, Growth and Public Policy, Max Planck Institute, 1-11. ftp://papers.econ.mpg.de/egp/discussionpapers/2005-10.pdf.

CHEN, C. (2014).Entrepreneurship, Economi Growth and Employment: A Case Study Of Taiwan. Hitotsubashi Journal of Economics 55, 71-88.

DORAN, J., MCCARTHY, N., O'CONNOR, M. (2018). The Role of Entrepreneurship in Stimulating Economic Growth in Developed and Developing Countries. Cogent Economics \& Finance, 6, 1-14.

GALINDO, M.A., MENDEZ, M. (2014). Entrepreneurship, Economic Growth, and Innovation: Are Feedback Effects at Work? Journal of Business Research 67, 825829.

GEM http://www.gemconsortium.org/ (Erişim Tarihi: 03.01.2018)

HÉBERT, R. F., LINK, A. N. (1989). In Search of Meaning of Entrepreneurship. Small Business Economics, 1 (1), 39-49.

KARAGÖZ, K. (2016). Girişimcilik-Ekonomik Büyüme İlişkisi: Türkiye İçin Ekonometrik Bir Analiz. JED/GKD, 11(2), 265-292.

ÖZKUL, G., ÖRÜN, E. (2016). Girişimcilik ve İnovasyonun Ekonomik Büyüme Üzerindeki Etkisi: Ampirik Bir Araştırma. Girişimcilik ve İnovasyon Yönetimi Dergisi, 5(2), 1751.

RUSU, V., ROMAN, A. (2017). Entrepreneurial Activity in the EU: An Empirical Evaluation of Its Determinants. Sustainability, 9 (1679), 1-16.

STAM, E., STEL, A. (2009). Types of Entrepreneurship and Economic Growth. World Institute for Development Economics Research. No: 2009/47, 1-16.

URBANO, D., APARICIO, S. (2016). Entrepreneurship Capital Types and Economic Growth: International Evidence. Technological Forecasting \& Social Change, 102, 34-44.

WENNEKERS, S., THURIK, R. (1999). Linking Entrepreneurship and Economic Growth. Small Business Economics, (13), 27-55.

WORLD BANK, http://databank. worldbank.org/data/reports.aspx?source=worlddevelopment-indicators Erişim Tarihi: 03.01.2018 